IJoLLT Vol 4, No. 1 (March) 2021

eISSN: 2637-0484

\title{
Keris Siamang Tunggal: Unveiling Malay Artistic Culture
}

\author{
WAN HALIZAWATI BT. WAN MAHMOOD \\ School of Languages, Literacies and Translation \\ Universiti Sains Malaysia \\ whaliza@usm.my
}

\begin{abstract}
One crucial effect of technological advancement is evident in the powerful increase in the production and worldwide movement of audiovisual materials, thus promoting wide scale access and consumption of telecinematic products for education, entertainment, leisure, as well as information gathering. On a related note, Audiovisual Translation (AVT) field has emerged into a mature field of research in Translation Studies, revealing rapid increase in the audiovisual content flow in different forms with comprehensive, descriptive and scientific approaches. The goal of this paper is to look into the depiction of Malay artistic treasures in a foreign setting. In addition to this, the paper analyzes the way the English subtitle of "Keris Siamang Tunggal" depicts each of the Malay cultural items in "Keris Siamang Tunggal". In this study, the author tested one of the successful Malaysia's animated films "Keris Siamang Tunggal" which has tremendously portrayed unique and historical Malay cultural items - Malay folklores iconic figures, royal language, and other Malay cultural items such as traditional weapons, literature, performing arts, classical words, slangs, forms of address, and food identity - by means of English subtitles and visuals/images. This local animated film was chosen for the discussion, while Katan's (2009) and Schwarz's (2002) guide on cultural items translation with regards to the classification of cultural items and the translation of the items in the context of audiovisual medium, were selected to build the basis of the investigation and steer this descriptive-based study. Katan's theory classifies etymology and types of cultural items, while Schwarz's theory seems to be useful, given that she focuses on cultural concept in films and that she relates them to the ones that appear on the screen. The result demonstrated that Keris Siamang Tunggal has portrayed 30 Malay cultural items, consisting of Malay folklores iconic figures, royal language and other Malay cultural items that covered traditional weapon, literature, performing arts, classical words, slang, forms of address, as well as food identity. From the 30 items, seven (7) were the iconic figures adapted from Malay traditional folklores, six (6) were the royal language, and 17 were other cultural items. This paper came to the vital conclusion that Keris Siamang Tunggal played a significant role in helping to shape and solidify Malay artistic treasures to the eye of western world, thus opening foreign audience's eyes to new ways of thinking, feeling and pursuing Malay culture.
\end{abstract}

Key words: Malay culture, subtitling, Keris Siamang Tunggal

Published online: April 2021

To cite this article: Wan Mahmood, W. H. (2021). Keris Siamang Tunggal: Unveiling Malay Artistic Culture. International Journal of Language, Literacy and Translation 4(1), 28-44. https://doi.org/10.36777/ijollt2021.4.1.041

To link to this article: https://doi.org/10.36777/ijollt2021.4.1.041

This work is licensed under the terms of the Creative Commons Attribution (CC BY) (https://creativecommons.org/licenses/by/4.0/). 


\section{INTRODUCTION}

The significant role of media in the globalized world and global communication era becomes unquestionable. With the increasing capacity of international movement of people and goods via the use of electronic devices, globalization as a vision of emphasizing a firm interconnection and intercommunication between people has enhanced this form of interaction and communication. On a related note, the exploration of media, translation and culture has been largely developed and began to be innovative in the last century. As a result, the field of translation studies namely audiovisual translation was born and dedicated to screen translation, enabling variety modes of subtitling, surtitling, dubbing, voice-over, audio description, narration, and interpreting, to transfer and share knowledge and information worldwide.

In the last few decades, audiovisual translation has experienced a "cultural turn, in which this "turn", coined by Bassnet and Lefevere (1998, p. 126), emphasizes greater work by translators in studying and exploring the process of cultural interchange, as well as understanding more about how different cultures construct the image of writers and of texts. Many different cultures have come into close contact with one another, demanding the dissemination of multi-culture.

It is also vital to note that although the cultural turn topic has aroused the interest of many scholars, in particular to that of literary translation scholars, the fact remains that it is relatively underdiscussed when it comes to audiovisual translation (Cintas, 2012). In fact, most studies in this field tended to emphasize more on the mechanics of the audiovisual translation and viewed it as an autonomous discipline. In this line of thought, Malay culture can be seen through its life, customs, traditions, and beliefs inherited from ancestors through generations (Hussain et al., 2020). Significantly, values on beliefs, ways of thinking, and culture have been the bases of the Malay cosmology. Therefore, it is interesting to see how the source cultural items are communicated to foreign audience of foreign countries in a different form of conveyance. With Malay cultural items being represented in foreign setting, in a new language namely English language, and in a new culture namely western culture, these efforts have provided a more realistic portrayal of the Malay artistic treasures to the target viewers of different parts of the world.

On that account, the author highlights the most crucial points of audiovisual translation which can be a justification of this paper. Subtitling the original Malay version of animated cartoons into other languages enables Malay culture - fables, legends, folklores, poems, musical instruments, even royal language - to be seen, appreciated, and conveyed to foreign audience. In fact, Malay world atmosphere can be viewed through its literature, which is filled with life, customs, traditions, cultures, and beliefs inherited from ancestors through generations (RobsonMcKillop, 2010). Therefore, the manifestation of the Malay world atmosphere by the creators of original texts is to make the target audience associate each setting or character with a detailed sociocultural environment, as well as giving them specific personality traits. It is the portrayal of the culture that leads to the introduction of the Malay cultural pattern to the targeted audience whom have never been exposed to this before while preserving the ambience of the culture.

However, the manifestation of Malay cultural items in foreign setting could become major challenge for translators towards finding and replacing appropriate items and making them comprehensible to the target readers. In addition, the translator, particularly in the field of audiovisual translation, is subjected to certain boundaries such as time, space, and other technical factors namely lip synchronization and the coordination movement of scenes, dialogues, images, and music. The impact of this issue is that the cultural items cannot simply be rendered into the 
target version as the translator needs to pay attention not only to every word but also to every scene, space, act and sound that simultaneously function at one time.

Finally, this paper attempts to investigate how original Malay version of cultural treasures are conveyed in English setting, thus triggering the complexity of local nuance representation to the western world. More essentially, the move made by the Les' Copaque Production was at the right time to sell Malaysia's image on the world stage, triggering the expansion of local cultural and ideological horizons of the Malay arts to the world.

\section{RESEARCH OBJECTIVE}

This paper inspires the author to analyse the Malay cultural portrayals in Keris Siamang Tunggal in the ways of identifying Malay cultural items, as well as analysing how English subtitle depicts each of the Malay cultural items found in the film.

The main issue is to look into what and how the Malay cultural items in Keris Siamang Tunggal have been rendered in a different setting of medium, environment and culture ambiance with regard to the English subtitles. This is crucial as the film has travelled the world, across linguistic and cultural borders, as well as making global connections and has been subtitled and dubbed into English language, with the title "Upin \& Ipin: The Lone Gibbon Kris", that were done in the United States. Indeed, Keris Siamang Tunggal is a good case study as it brings in a varied range of iconic figures that represent very strong Malay cultural expressions, folklores, and classical performances and songs to penetrate the international market of media industry.

\section{RESEARCH QUESTION}

Based on the justifications in the problem statement and the explanation of the objectives of this paper, the researcher examines two research questions. First, what are Malay cultural items found in Keris Siamang Tunggal? Second, in what way does the English subtitle depict each of the Malay cultural item in Keris Siamang Tunggal?

\section{RESEARCH SIGNIFICANCE}

This paper is more significant for subtitlers, in particular with the translation of cultural texts. It focuses on Malaysian animated films that went globally, in this case Keris Siamang Tunggal, which are suitable mediums that expose the western world to our local cultural items. Moreover, it is crucial to the local animation industry given that it provides sufficient opportunity to dialogue or script translators to employ specific and appropriate methods of translation with regards to cultural words.

\section{LITERATURE REVIEW}

The main purpose of this section is to provide a background on subtitling mode and artistic treasures of Malay folklores and royal language in general, and the translation of cultural items in particular.

Cintas (2020) emphasizes the connotation of 'subtitling' which refers to a translation practice that consists of rendering in writing, and at the bottom of the screen. It is in a form of written text that renders original spoken dialogue into target language. He scrutinizes the main translational 
challenges of subtitling as film subtitles involve not only interlingual but mainly intersemiotic translation, in which visual message complements the verbal one.

The above point brings to the vital issue of the nature of culture-specific items translation which becomes one of the greatest challenges for translators. Translators come across words that have specific meaning in each culture, hence bringing biculturalism as an important asset for them. Many scholars have discussed this issue, while different approaches have been described within the discipline of Translation Studies. In the context of this paper, the main issue is what and how Malay cultural items of folklores iconic figures, royal language and other Malay cultural items have been rendered in a different setting of medium, environment and culture ambiance with regard to English subtitles.

Mohd Taib Osman (1988) emphasizes that Malay traditional storytelling was based on its culture that has been adapted from the surroundings according to the time the stories were narrated. It is a tradition, knowledge, language and guides that have been passed down from generation to generation in various forms - either in written or oral traditions. Among the eminent Malay folklores are "Tanjong Puteri" and "Seri Mersing", and bardic wisdom or Cerita Penglipur Lara, for instance "Singapura Dilanggar Todak", "Pak Pandir", "Raja Bersiong", and 'Nujum Pa' Blalang".

It is an undeniable fact that most of the Malay folklores revolve around kings or sultans and their kingdom or people as can be seen in Cerita Penglipur Lara, for instance "Singapura Dilanggar Todak", "Raja Bersiong", "Hikayat Malim Deman", "Hikayat Malim Dewa" among others. Therefore, the folklores always come with the use of royal language by regal and commonalty characters as part of the plot.

Royal language, according to Asmah Haji Omar (2004), refers to the use of decent or polite language variation among royal family, as well as the means of ordinary people communicating with the royal family. It has features in common with classical Malay. The use of specific features such as its vocabulary and expressions depict the uniqueness, beauty and richness of this language. In fact, royal language in Malaysian context is a heritable form of speech and communication, from ancient times to the present.

Looking from the perspective of Malay royal family, or to be specific, Malay Sultanate, the vocabulary and phrase used in the royal language among them are different from how the formal Malay language is spoken, thus depicting the uniqueness, beauty, and richness of this language. It is a superior language to demonstrate the supreme cultural values of Malays, in particular with courtesy and good breeding. As it is associated with royal court, it has become the highest form of courtesy passed down from generation to generation. For instance, the word 'santap' is used to refer the ordinary Malay word 'makan' (to eat), while 'beradu' is to refer the word 'tidur' (to sleep), and 'bersiram' represents 'mandi' (to bathe). Likewise, 'patik' represents the Malay form of address 'saya' (I/me) while 'beta' is the way the Kings or Sultans address themselves.

Accordingly, Zainal Abidin Ahmad (1934) provided guidance in lexical selection of royal language. He suggests sentence restructuring and modification method, instead of word-to-word translation, in rendering the meaning of the text. This is essential as royal language lexical system has different class of words and that they must be used in appropriate context and situation.

Rahman and Ahmad (2017) analysed the ancient symbolism of God-King among people in Southeast Asia and that it has significant influence on Malay literature. They argue that there was description about royal family in Malay folklores in which the narration was well crafted in order to attract commonalties to read the folklores. The result of this study also demonstrated that the 
use of symbolism of God-King and the royal language was to put emphasis on the sovereignty of Malay rulers.

Slavova and Borysenko (2018) specified the characteristic features of rendering cultural information in English-Ukrainian translation. The study demonstrated that culture is coded and reflected in the language, leading to the conclusion that while translating languages, translators translate their cultures as well. Rendering dialogues between the two different cultural communities is one of the major problems seeing that the task is complicated due to the necessity to reproduce the relations between the cultures communicated in the source they text belong to. The study also argued that in case of realia translation, the emphasis is on the preservation of the pragmatic and cultural effect which can be done at the expense of the form.

Finally, Neshkovska (2018) investigated translation strategies in transferring cultural items from a source text to a target text. She suggested that translators are entrusted with the task of bridging cultural differences and enabling the target text recipients to comprehend the whole original message, just like the source text receptors. Next, she emphasised that many translation theorists purport the difficulties in translating cultural items. In that respect, they classify the culture-specific terms in various domains and propose numerous translation strategies for rendering culture-specific terms.

\section{METHODOLOGY}

The data used in this study consists of Malay cultural items found in Malaysia's animated film Keris Siamang Tunggal, namely Malay folklores iconic figures, royal language and other Malay cultural items, viz. traditional weapons, literature, performing arts, classical words, slangs, forms of address, and food identity. This 100-minute feature film of adventure, family and fantasy genre was released in March 2019 with the English title "Upin \& Ipin: The Lone Gibbon Kris". The quest of Upin \& Ipin with their friends Ehsan, Fizi, Mail, Jarjit, Mei Mei, Susanti began when they were sucked in, along with Keris Siamang Tunggal, by Devouring Rock (Belah Batu Bertangkup) into another world called Inderaloka. The long journey was to save the fantastical kingdom of Inderaloka from an evil king, Raja Bersiong (The Fanged King), the legendary but mean king known for the abuse of his power, leading to the downfall of Inderaloka.

While trying to help Inderaloka, they were accompanied by well-known Malay folktales characters - from Mat Jenin and Belalang to Si Tanggang and Bawang Merah dan Bawang Putih. Upin, Ipin and their friends who tried to overcome a series of challenging obstacles in this action-packed and magical adventure animated film. In fact, the appearance of several Malay folklore figures from numerous evergreen folklores made the film a truly Malay artistic treasure to be disclosed to the eyes of the world. In other words, Keris Siamang Tunggal brings in a varied range of iconic figures and other cultural portrayals such as traditional songs and musical equipment that represent very strong Malay culture and custom in foreign setting.

Interestingly, though Keris Siamang Tunggal depicts the classical journey of Malay folklores and royal families, with the use of formal royal language in certain dialogues, the film also includes formal and non-formal Malay language seeing that it also aims at children for the purpose of educating and providing them light entertainment. Therefore, the translation of this film genre is not only expected to be easily understood by the young viewers but also to conform to social norms and maintain the source text's educational and leisure functions, thus triggering the complexity of local nuance representation to the western world. 
This paper employed text analysis as its research methodology, which mostly applied a qualitative description through subjective report, explanation, and interpretation.

The corpus of this study consists of the English subtitles and images/visuals which were extracted from the samples of the animated film Keris Siamang Tunggal. The author first identified types of Malay cultural items portrayed in the film as stated by Katan (2004). Katan argued that cultural words refer exclusively to humanist ideal of what is civilized in a developed society, for instance, education system, arts, and architecture. However, for broader sense of cultural items categories, upon which is to significantly indicate that culture connotation also refers to people's way of life, he classified the items as follows: environment (people, setting, artefacts), strategies (ideas, spoken/written styles, habits, customs), value beliefs, identities (national, ethnic, gender, religious, class, role, individual personality, text actors or characters, personalities, animated subject). Therefore, with the development of sociology and cultural studies in translation area, the author related the classification to what have been depicted in Keris Siamang Tunggal - Malay folklores iconic figures, royal language as well as other Malay cultural items. The identification is crucial in order that the local cultural items of the original version could be made known to the foreign audience. Therefore, this study engages the target audience in these customs and traditions by explaining what they were about besides equating unfamiliar cultural words with suitable equivalence in the target culture.

The author then analysed the language of the English subtitles, as well as images and visuals on the screen, by looking into the suitability of the English translation according to Schwarz's theory of cultural portrayal on the screen. The analysis employed Schwarz's theory (2002) which argues that a translator identifies visual clues within a film and understand their significance in source language culture depending on the two cultures involved. In other words, the audiovisual translator must fully comprehend and properly interpret all the different aspects of the film either verbal or non-verbal clues, facial expressions, hand gestures and body language as the audiovisual materials appeal to eyes and ears simultaneously. In this sense, the implied messages are not only hidden in the language but can be found visually and orally. The visuals on the screen indeed help the subtitler to interpret words that denote certain meaning. In addition, the soundtrack can also contribute to the features of the translation by evoking images or emotions with sounds, visuals and music.

Finally, the author provided recommendations to subtitlers in terms of increasing the level of efficiency in the translation of cultural items of audiovisual materials. This is vital as the concept of text in audiovisual translation is very much different from what was found in other written translation due to the existence of multi-semiotic mixture of many different codes, namely images, sounds, colors, proxemics, kinesics, and narrative.

For the purpose of this paper, English transcripts of Keris Siamang Tunggal were extracted from local Malaysian satellite television provider, ASTRO via one of its channels ASTRO On Demand. The data were marked according to the types of Malay cultural items depiction in terms of subtitle texts and visuals or images, namely Malay folklores iconic figures (FFs for the subtitles, and FFv for the visuals), royal language (RL) and other Malay cultural items (OCs for the subtitles, and $\mathrm{OCv}$ for the visuals), with data sequential numbers (e.g. FFs1, FFs2, FFv1, FFv2, RL1, RL2, OCs1, OCs2, OCv1, OCv2). The data were also listed according to the sequencing, which refer to events within a given text in the order in which they occurred.

\section{FINDINGS AND DISCUSSION}


The results are presented into two main parts as stated in the research questions: the analysis results of Malay cultural items found in Keris Siamang Tunggal, and the analysis results of the way the English subtitle depicts each of the Malay cultural items in Keris Siamang Tunggal.

The results of types of Malay cultural items found in Keris Siamang Tunggal were based on Katan's theory of cultural items classification, while the results of the depiction of the English subtitles were based on Schwarz's theory that focuses on cultural concept and its appearance in films as 'moving material'.

The results of types of Malay cultural items and their depictions by means of English subtitles are demonstrated in Table 1 as follows:

Table 1

Keris Siamang Tunggal's Malay cultural items depiction

\begin{tabular}{lll}
\hline Malay dialogues & English subtitles & \multicolumn{2}{c}{ Remarks } \\
\hline Waah! Banyaknya keris & OCs1, OCv1 Wow! So many kris & $\begin{array}{l}\text { OCs1, OCv1: subtitle + visual: A } \\
\text { visual of several 'keris' (Malay } \\
\text { daggers) inside a colonial. }\end{array}$
\end{tabular}

FFs1, FFv1 I'm Captain Ipin

Akulah Hang Ipin

Batu Belah Batu

Bertangkup

OCs2, OCv2 The Devouring Rock

FFs2, FFv2 Mat Jenin

Mat Jenin

Si Tanggang F F, FFv3 Si Tanggang

Todak Melanggar Singapura
OCv3
FFs1, FFv1: subtitle + visual: A visual of Ipin standing on the colonial chest, holding a kris.

OCs2, OCv2: subtitle + visual: Adapted from Malay fable "Batu Belah Batu Bertangkup". This is where the quest of Upin \& Ipin began when they were sucked in by Devouring Rock (Belah Batu Bertangkup) into another world called Inderaloka kingdom.

FFs2, FFv2: subtitle + visual: A legendary character of daydreamer in Malay fable. Adapted from "Hikayat Mat Jenin". A visual of Mat Jenin resting and dreaming on a coconut tree after picking coconuts.

FFs3, FFv3: subtitle + visual: A legendary character of ungrateful son. A visual of the boulder Tanggang on a ship after being cursed by his biological mother.

OCv3: Adapted from Chapter 4 of The Malay Annals "Singapura Dilanggar Todak". A scene 
IJoLLT Vol 4, No. 1 (March) 2021

eISSN: 2637-0484

Raja Bersiong

Pak Belalang

Merah

Putih

wayang kulit
FFs4, FFv4 Raja Bersiong

FFs5, FFv5 Pak Belalang

FFs6, FFv6 Merah

FFs7, FFv7 Putih

OCv4 resembles

Singapore.

FFs4, FFv4: subtitle + visual: Adapted from "Hikayat Raja Bersiong”. A visual of The Fanged King, a renowned barbarous and rogue ruler fighting with The Sultan of Inderaloka kingdom.

FFs5, FFv5: subtitle + visual: A visual of Pak Belalang, a lazy man who became a successful fortune teller in Malay humorous tales " $\mathrm{Pa}$ ' Belalang"

FFs6, FFv6: subtitle + visual: Adapted from one of the best Malay folklores "Bawang Putih Bawang Merah". A visual of Merah singing "Buai Laju-Laju" on a beautiful and magical swing in the woods to deal with grieve and sadness.

FFs7, FFv7: subtitle + visual: Merah's twin sister Putih was put in prison for accusing her twin sister.

OCv4: A visual of 'wayang kulit' performance at Megah Harbour dock.

OCs3: Part of the film's song lyric "Keris Sakti" consisting of Malay classical words and was translated into English subtitle:

Tujuh petala langit menyeru namanya,

Tujuh petala Bumi gerun akannya, Seven heavens call upon its name Seven lands tremble at its fame

OCs4: Part of the film's song lyric "Keris Sakti" using Malay classical words:

Tujuh petala langit menyeru namanya,

Tujuh petala Bumi gerun akannya Seven heavens call upon its name Seven lands tremble at its fame

OCs5: A fantasy realm named Inderaloka and was under control of Raja Inderaloka (King of Inderaloka). It is also a Malay classic word referring to 'heaven'. 
IJoLLT Vol 4, No. 1 (March) 2021

eISSN: 2637-0484

\begin{tabular}{|c|c|}
\hline Raja sangat murka! & RLs1 The King is furious! \\
\hline ayahanda & RLs2, RLv2 father \\
\hline anakanda & RLs3, RLv3 son \\
\hline beta & RLs4 I, me \\
\hline Patik menjunjung titah, Tuanku & $\begin{array}{l}\text { RLs5, RLv4 Yes, Your Royal } \\
\text { Highness }\end{array}$ \\
\hline
\end{tabular}

Daulat Tuanku!

RLs6, RLv5 Long live The King

Panglima

OCs6, OCv5 Commander

Kami lah kelana

OCs7, OCv6 We are travelers

Buai laju-laju

Buaikan diriku

OCs8, OCv7 Swinging swiftly .....and free

OCs9, OCv8 Atok

OCs10, OCv9 Opah
RLs1: Royal language referring to 'angry/enraged', referring to Raja Bersiong.

RLs2, RLv2: subtitle + visual: Royal language referring to form of address of 'father'. A visual of Inderaloka's King talking to his son.

RLs3, RLv3: subtitle + visual: Royal language referring to form of address of 'son'. A visual of Inderaloka's King's son talking to his father.

RLs4: Royal language referring to form of address of ' $I / m e$ '

RLs5, RLv4: subtitle + visual: Royal language to obey King's command. A visual of Panglima pledging to obey King's command

RLs6, RLv5: subtitle + visual: A visual of people cheering on the King.

OCs6, OCv5: subtitle + visual: A classic designation of high rank officer in Malay ancient military/navy. A visual of 'Panglima' fighting with his rivalry, Raja Bersiong.

OCs7, OCv6: subtitle + visual: Part of song lyric using Malay classical words, chanted by Upin, Ipin, and their friends as they marched towards the Inderaloka palace. A visual of Upin \& Ipin's defense team marching towards the Palace.

OCs8, OCv7: subtitle + visual: Part of melodious song lyric sung by Putih on a beautiful and magical swing in the woods to deal with grieve and sadness:

"Buai laju-laju, buaikan diriku Buai laju, gembirakan hati ku". A visual of Putih singing the song on her magical swing.

OCs9, OCv8 subtitle + visual: Malay form of address referring to 'grandfather' (grandpa). A visual of Upin \& Ipin's great-uncle.

OCs10,

OCv9: subtitle + visual: Malay form of address referring to 'grandmother' 
Akak

OCs11, OCv10 Akak

"Dua, tiga..."

Nah!

$\mathrm{ABCD}$
OCs13, OCv11 Fantastic!

OCs14, OCv12 Here you go! / Here!

OCs15, OCv13 Shaved ice
OCs11, OCv10: subtitle + visual: Malay form of address referring to 'sister' (sis). A visual of Upin \& Ipin's sister, Kak Ros.

OCs12: Jarjit's self-made pantuns, in Upin \& Ipin television series, his self-identity in commencing and delivering conversation with other friends.

OCs13, OCv11: Malay informal strong interjection indicating that one is stunned or impressed by something. A visual of Nakhoda Ragam when entering the superb Inderaloka Kingdom.

OCs14, OCv12: Malay informal interjection used when giving something to others (as portrayed in this film). A visual of

Prince Inderaloka giving something to Upin \& Ipin.

OCs15, OCv13: Malaysian icy cold dessert or ice-cream which is commonly known as 'ABC' (air batu campur / mixed ice). 'ABCD' is only available at Uncle Muthu's stall (one of the characters in Upin \& Ipin television series). A visual of $\mathrm{ABCD}$ preparation by Uncle Muthu.

\section{A. MALAY CULTURAL ITEMS}

From the data of Table 1, it was found that the Malay custom and culture in Keris Siamang Tunggal have been realistically portrayed, by means of the English subtitle along with the verbal and non-verbal visuals, to the target audience who do not share the original culture and linguistic situation. The author managed to gather 30 Malay cultural items, consisting of iconic figures of Malay folklores, royal language and other Malay cultural items that covered traditional weapons, literature, performing arts, classical words, slangs, forms of address, as well as food identity. Figure 1 demonstrates the details: 


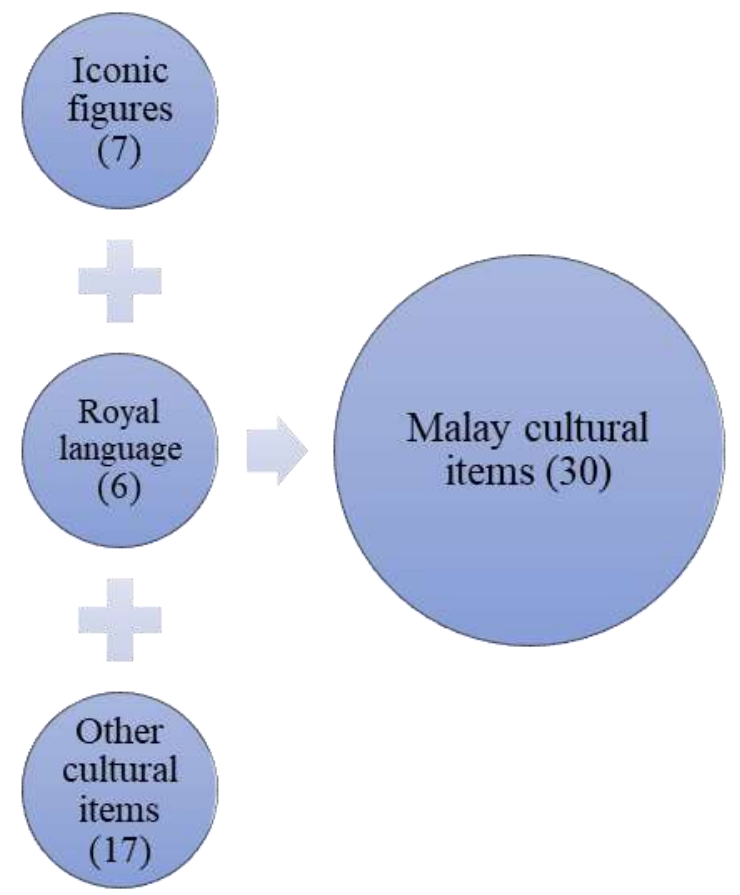

Figure 1: Breakdown of Malay cultural items

FFs1, FFv1 "I'm Captain Ipin" was an adaptation of one of the legendary five warrior brothers of Malay world, Hang Tuah, as a result of its original dialogue "Akulah Hang Ipin". Keris Siamang Tunggal has made the name "Hang" conspicuous by fitting the character as the superior icon while proudly holding the kris, a symbol of sovereignty of Malay rulers.

The depiction of Malay popular character Mat Jenin, along with the visual (FFs2, FFv2), was adapted from a legendary character of daydreamer in the timeless Malay folklore "Hikayat Mat Jenin". Although the plot setting was different from what has been narrated in the original "Hikayat Mat Jenin", Keris Siamang Tunggal managed to represent the traits of Mat Jenin by visualizing him resting and dreaming on a coconut tree after picking coconuts, and that in his dream, he was able to find his cows and horse after selling the coconuts.

Si Tanggang (FFs3, FFv3), on the other hand, was visualized as man-like boulder on a big ship. The character was taken from a legendary character of ungrateful son of Mak Deruma, the woman who also appeared in Keris Siamang Tunggal, waiting for his son to be back from his long-lost journey, seeking his fortune. The visual of the boulder was the aftermath of Mak Deruma's curse upon realizing his biological son's claim that she was rather 'an insane old woman' who tried to expropriate his wealth.

Likewise, the FFs4, FFv4 of Raja Bersiong was personalized from "Hikayat Raja Bersiong" of the ancient Malay document "Hikayat Merong Mahawangsa" or Kedah Annals. This 'Fanged King' was a renowned barbarous and rogue ruler by his strange nature of enjoying his everyday meal added with human blood. However, Keris Siamang Tunggal has slightly modified the 
original narration of "Hikayat Raja Bersiong" by portraying Raja Bersiong's evil plan to destroy the Inderaloka Kingdom.

Finally, FFs6 and FFs7 Merah and Putih were adapted from Bawang Putih Bawang Merah which is one of children's book of fables bedtime folklore. This story touches on familial values, patience in the face of adversity, and that ultimately the good (Bawang Putih) will be rewarded while the evil (Bawang Merah) will be punished.

From the above explanation, it can be concluded that the distinctive figures portrayed in this film used the retention method in the characters' names have strong potential of being recognized outside Malaysia, thus enriching Malay literature throughout the world.

From the perspective of royal language, the use of the language in the source dialogues of Keris Siamang Tunggal could become an appropriate platform in introducing the environment of esthetic Malay Sultanate kingdom back in the $15^{\text {th }}$ century. It proves that the language is the original soul of ancient Malay community and that it symbolizes commoners' courtesy and honorific when speaking to the King or Sultan which is hardly to find but in monarchism countries.

RL1 The King is furious!', RL2 father, RL3 son, and RL4 I, me are the representations of ordinary Malay words 'marah' (to be angry), 'bapa/ayah' (father), 'anak' (child/son/daughter), and 'saya' (I/me), respectively, while establishing the high-esteem of the language in western ambiance.

Finally, the cultural items portrayed in Keris Siamang Tunggal revolve around some other Malay identities as follows:

Table 2:

Other Cultural Items

\begin{tabular}{lll}
\hline \multicolumn{1}{c}{ Items } & Malay text & Remarks \\
\hline traditional weapon & OCs1 keris & $\begin{array}{l}\text { kris (type of dagger, } \\
\text { symbol for Malay } \\
\text { royalty and } \\
\text { dignitaries) }\end{array}$ \\
literature & $\begin{array}{l}\text { OCs2 Batu Belah } \\
\text { Bertangkup; } \\
\text { OCv3 Todak } \\
\text { Melanggar Singapura }\end{array}$ & Malay fables \\
& OCs11 Jarjit's pantun & Malay rhymed poem \\
performing arts & OCv4 wayang kulit & shadow play \\
\hline
\end{tabular}




$\begin{array}{lll}\text { classical words } & \begin{array}{l}\text { OCs6 Inderaloka } \\ \text { OCs4, OCs5 petala } \\ \text { OCs7 kelana }\end{array} & \begin{array}{l}\text { paradise } \\ \text { layer } \\ \text { traveler }\end{array} \\ \text { form of address } & \begin{array}{l}\text { OCs9, OCv8 atok } \\ \text { OCs10, OCv9 opah } \\ \text { OCs11, OCv10 akak }\end{array} & \begin{array}{l}\text { grandpa } \\ \text { grandma } \\ \text { sister/sis }\end{array} \\ \text { linguistic variation } & \begin{array}{l}\text { OCs13, OCv11 fuyyoo! } \\ \text { OCs14, OCv12 Nah! }\end{array} & \begin{array}{l}\text { interjection: wow! } \\ \text { Here you go! / Here! }\end{array} \\ \text { food } & \text { OCs15, OCv13 ABCD air } & \begin{array}{l}\text { local ice-cream/ } \\ \text { shaved ice }\end{array} \\ & \text { batu campur } & \\ & & \\ & & \end{array}$

From the explanation given, it can be concluded that the Keris Siamang Tunggal has credibly portrayed Malay artistic culture namely Malay folklores iconic figures, royal language, and other Malay cultural items covering traditional weapons, literature, performing arts, classical words, slangs, forms of address, and food identity. All the items served to inform foreign audience about the meaning, idea, knowledge, and concept of different entities. It is also vital to note that the Malay treasures are capable to travel the world, to cross linguistic and cultural borders, to make global connections and the most important point is to give new life to the world of human's life.

\section{B. KERIS SIAMANG TUNGGAL'S ENGLISH SUBTITLE}

The data referring to subtitle of the three variables were marked with "...s" to distinguish them from the data with visuals $(\ldots \mathrm{v})$. From the data gathered, it was found that the creation of English subtitle for Malay cultural items in Keris Siamang Tunggal was mostly supported by related visuals that were concurrently displayed with the original dialogues. In other words, the depiction of the iconic figures, royal language, and other Malay cultural items namely traditional weapons, literature, performing arts, classical words, slangs, forms of address, and food identity into English subtitle was clearly demonstrated by means of 'on-screen physical appearance' benefit. Furthermore, the language used in the English subtitles, including the translation of the royal language, is short and easy, with mild and common vocabulary and appear in one line at a time, allowing effortless comprehension for young viewers who are the major audience of this film.

For instance, the names of seven iconic figures namely Hang Ipin, Mat Jenin, Si Tanggang, Raja Bersiong, Pak Belalang, Merah, and Putih (FFs1, FFv1; FFs2, FFv2; FFs3, FFv3; FFs4, FFv4; FFs5, FFv5; FFs6, FFv6; FFs7, FFv7, respectively) were retained as in the original version. The author believes that the retention method of the names is vital seeing that the names of the iconic figures in Malay folklores represent the real authentic of its literature - semantically, historically, geographically, and culturally loaded.

As emphasized in the theoretical framework section, the implied messages of Keris Siamang Tunggal were not only hidden in the spoken dialogues but can also be found visually. The visuals indeed helped the subtitler to render the cultural items that denote certain meaning. 
Next, the challenge in translating royal language and classic language in Keris Siamang Tunggal is to maintain the compatibility of modern Malay language syntax elements without disregarding the beauty of the language at the heart of classical Malay text. The expressions were mostly rendered into English subtitle with the help of on-screen visuals and descriptions. For example, "Raja sangat murka!/ RLs1 The King is furious!" was uttered by Pak Belalang to Inderaloka King's son while describing the evil plan of Raja Bersiong to conquer the royal insignia Keris Siamang Tunggal, provoking the wrath of the King. However, the subtitler made a prudent choice by selecting the word 'furious' (feeling great anger), instead of 'angry' (displaying or feeling anger), to strengthen the degree of Inderaloka King's anger. Unlike common and standard Malay word 'marah' used by the ordinary people when they are in the atmosphere of anger or dissatisfaction, the author believes that the choice of the word 'furious' corresponds to the degree of Malay Kings' or Sultans' expression of disagreement, namely 'murka' on certain matters, particularly when it comes to nation and people's welfare.

Further highlighted examples of the uniqueness of royal language can be seen in "Patik menjunjung titah, Tuanku/ RLs5, RLv4 Yes, Your Royal Highness". Generally, the form of address for Malaysian Sultans is "His Royal Highness", except for the Sultan of Johore which has been changed to "His Majesty". The same rule applies to the British royal family, with the title used in the first instance being 'Your Royal Highness'. In this example, the author also observes 'patik' which is a Malay humble form of address of 'I' or 'me' used by commoners when addressing royalty. Similarly, "RLs2, RLv2 father" and "RLs3, RLv3 son" are the replacements for royal forms of address of 'ayahanda' and 'anakanda', respectively. Finally, '... menjunjung titah' refers to 'obeying King's or Ruler's command'. This phrase was translated as "Yes...." to equate the connotation of 'obeying King's command' while "Your Royal Highness" is the way of royal language addressing "Tuanku" or the King/Sultan.

Despite losing 'royal' connotation in the English subtitle due to the absence of English equivalence for 'patik' (I/me), 'ayahanda' (father), 'anakanda' (son), and '... menjunjung titah' (Yes...), as well as realizing the fact that in the process of creating English subtitle of Keris Siamang Tunggal, there might be some sort of loss of meaning due to different factors to the environment and culture of the language, the audiovisual material does provide visuals of related scenes, serving to provide comprehension to the audience about the concept of royal language. Therefore, these traits of subtitling tremendously helped the Keris Siamang Tunggal in reaching out the elements of Malay royal language to its foreign audience.

Meanwhile, in translating song "Buai laju-laju, Buaikan diriku/OCs8, OCv7 Swinging swiftly.... and free", the author admits the subtitler's difficulty in preserving its rhythm in the subtitles. However, Schwarz claims that it might be impossible to find such rhyming words in the target language, but there is still a leeway to keep the rhythm, that is by searching for words with similar number of syllables or the sound of the word that composes the target song. From this point of view, the author found out that the English lyric was very much adhered to the composition of the original lyric in terms of the sound of the words that composes the target lyric (repetition of 'buai' and ends with vowel ' $u$ ' in both verses of original lyric, and the sound uniformity of 'ee--' in both verses of target lyric), while retaining the original meaning (description of the magical swing) in the target song. Furthermore, the film provides short and simple language of song subtitle to be understood by the audience, and appeared in one line at a time, enabling the song to be easily informed to the audience.

Finally, the translation of Malay informal interjections "Fuyyo!/OCs13, OCv11 Fantastic!" and "Nah!/OCs14, OCv12 Here you go! / Here!" was created according to their sound 
interjections whose function is realized by the way they sound. As for "Fuyyo!", this informal interjection signals the stunning and impressive feelings which is equivalent to the connotation of "Fantastic!", while "Nah!" signals the act of giving something. The two have accordingly been rendered into English subtitles, supported by the visuals that portrayed physical actions leading to the functions of the interjections by the way they sound.

From the explanation given, it can be concluded that the English subtitles of the Malay cultural items in Keris Siamang Tunggal were created in such a way of retaining all the iconic figures' names and modulating the royal language into short and simple subtitles, with mild vocabulary for the purpose of reproducing the original message in the target language text in accordance with the current norms of the target language. The subtitles were also supported by related visuals that were concurrently displayed with the original dialogues. All these were the translators' efforts in assisting the target audience to make better judgments of the source contents while making the film as ambassadors of Malay literature.

\section{CONCLUSION}

This paper analysed the Malay cultural portrayals in one of the Malaysian animated films Keris Siamang Tunggal with the main objectives of identifying Malay cultural items, as well as analysing how the English subtitle depicts each of the Malay cultural items in the film. From the critical analysis and explanation, the author concluded that Keris Siamang Tunggal is a good medium to sell Malaysia's image and cultural identity on the world stage, as well as helping expand the cultural and ideological horizons of Malay arts to the world.

On a related note, the Keris Siamang Tunggal's English subtitles applied short, simple, and common words, as well as applying retention method for the iconic figures' names and the modulation method in the royal language dialogues so as to be understood by target audience while allowing the Malay cultural items to easily inform the audience about the meaning, idea, knowledge, and concept of different entities.

\section{REFERENCES}

Asmah Haji Omar. (2004). Bahasa Diraja. Kuala Lumpur: Dewan Bahasa dan Pustaka.

Bassnett, S. (2007). Culture and translation. A companion to translation studies. 13-23. https://doi.org/10.21832/9781853599583-003

Browning, T. (1993). A brief historical survey of women writers of science fiction. Retrieved from http://www.cwrl.utexas.edu/ tonya/Tonya/sf/history.html

Davis, S. G. (2010). ben botkin's Fbi File. Journal of American Folklore, 123(487), 3-30. https://doi.org/10.5406/jamerfolk.123.487.0003

Díaz Cintas, J. (2012). Clearing the smoke to see the screen: Ideological manipulation in audiovisual translation. Meta: journal des traducteurs/Meta: Translators' Journal, 57(2), 279-293. https://doi.org/10.7202/1013945ar

Díaz-Cintas, J. (2020). The Name and Nature of Subtitling. In The Palgrave Handbook of Audiovisual Translation and Media Accessibility (pp. 149-171). Palgrave Macmillan, Cham.

Ding, C. M. (2004). The Malaysian Baba Pantun Database. Sari Journal, 22, 159-165. 
Gambier, Y.(ed.). 1997. Language Transfer and Audiovisual Communication. A Bibliography.

Turku: Centre for Translation and Interpreting

Gambier, Y. (2003). Screen trans-adaptation: Perception and reception. The Translator, 9(2), 171-189. https://doi.org/10.1080/13556509.2003.10799152

Gambier, Y., \& Gottlieb, H. (Eds.). (2001). (Multi) media translation: concepts, practices, and Research. (Vol. 34). John Benjamins Publishing. https://doi.org/10.1075/btl.34

Gambier, Y., Shlesinger, M., \& Stolze, R. (2004). Doubts and directions in translation studies: Selected contributions from the EST congress.

Gambier, Y. (2006). Multimodality and Audiovisual Translation. Audiovisual Translation Scenarios. Proceedings of the EU-High Level Scientific Conference Series.18.

Gambier, Y. (2009). Challenges in research on audiovisual translation. Translation research Projects. 2, 17-25.

Gambier, Y., \& Van Doorslaer, L. (Eds.). (2010). Handbook of translation studies (Vol. 1). John Benjamins Publishing. https://doi.org/10.1075/hts.1

Hadijah Hamat (2006). Peranan dan Perkembangan Sastera Kanak-kanak. Kuala Lumpur: Dewan Bahasa dan Pustaka.

Hill, A. H. (1956). The Kerris and other Malay Weapons. Journal of the Malayan Branch of the Royal Asiatic Society, 29(4 (176), 7-67.

Hussain, M. A., Mohd Yunos, M. Y., Ismail, N. A., Ariffin, N. F. M., \& Ismail, S. (2020). A Review of the Elements of Nature and the Malay Cultural Landscape through Malay Literature. Sustainability, 12(6), 2154. https://doi.org/10.3390/su12062154

Katan, D. (2009). Translation as intercultural communication. The Routledge companion to translation studies, 74, 92.

Liebes, T., \& Katz, E. (1990). The export of meaning: Cross-cultural readings of Dallas.

Md Sidin Ahmad Ishak (2005) Perkembangan Sastera Kanak-kanak di Malaysia. Shah Alam: Cerdik Publications Sdn. Bhd.

Mohd. Taib Osman. (1988). Kebudayaan Melayu dalam Beberapa Persoalan, KL: DBP.

Neshkovska, S., \& Kitanovska-Kimovska, S. (2018). Translating Culture. HORIZONS, Series A. XXII. https://doi.org/10.20544/HORIZONS.A.22.1.18.P14

Othman Puteh (1984). Sekitar Sastera Kanak-kanak dan Remaja. Kuala Lumpur: Dewan Bahasa dan Pustaka.

Rahman, P. N. A., \& Ahmad, Z. (2017). Hubungan Simbolisme dan Spiritualisme Dewa-Raja dalam Kesusasteraan Melayu Klasik. Kemanusiaan: the Asian Journal of Humanities, 24(2). https://doi.org/10.21315/kajh2017.24.2.5

ReMael, A., Orero, P., \& Carroll, M. (2012). Audiovisual translation and media accessibility at the crossroads: Media for all 3. BRILL. https://doi.org/10.1163/9789401207812

Robson-McKillop, R. (Ed.). (2010). The Epic of Hang Tuah. ITBM.

Schwarz, B. (2002). Translation in a confined space. Translation Journal, 6(4).

Slavova, L., \& Borysenko, N. (2018). Rendering cultural information in translation. Одеський лінгвістичний вісник, (11), 167-173. https://doi.org/10.32837/2312-3192-2018-11-167-

173

Strand, M. \& Eavan, B. (2000). The Making of a Poem: A Norton Anthology of Poetic Forms. New York: W. W. Norton \& Company.

Szarkowska, A., Cintas, J. D., \& Gerber-Morón, O. (2020). Quality is in the eye of the 
stakeholders: what do professional subtitlers and viewers think about subtitling?. Universal Access in the Information Society, 1-15.

Wilkinson, R. J. (1957). Papers on Malay Customs \& Beliefs. Journal of the Malayan branch of the Royal Asiatic Society, 30 (4 (180), 1-87.

Wilkinson, R.J. and Winstedt, R.O. (Eds.). (1961). Pantun Melayu. Singapura: Malaya Publishing House.

Zainal Abidin Ahmad. (1934). Ilmu Mengarang Melayu. Kuala Lumpur: Dewan Bahasa dan Pustaka. 